\title{
Effect of Total Solar Radiation and Rainfall on Yield of Different Tea (Camellia sinensis [L.] O. Kuntze) Clones at Two Sites in Kenya
}

\author{
Joseph Kimutai Langát ${ }^{1}$ \\ ${ }^{1}$ Faculty of Agriculture and Natural Resources Management, Kisii University, Kisii, Kenya \\ Correspondence: Joseph Kimutai Langát, Faculty of Agriculture and Natural Resources Management, Kisii \\ University, Kisii, Kenya. Tel: 254-722-305-965. E-mail: drjosephlangat@gmail.com
}

Received: March 16, 2018

Accepted: April 17, $2018 \quad$ Online Published: May 15, 2018

doi:10.5539/jas.v10n6p40

URL: https://doi.org/10.5539/jas.v10n6p40

\begin{abstract}
Tea cultivation is the leading cash crop in Kenya, making significant contribution to the economy. It is the single largest export commodity, accounting for about $26 \%$ of the country's total export earnings. In 2017 , the country got US\$ 1.23 billion in foreign exchange earnings. However, tea production is affected by weather changes. Majority of research reporting the effects of weather on tea yields in Africa have mostly been carried out at single sites. This study investigated contribution of total solar radiation and rainfall to tea (Camellia sinensis) yields at two sites in Kenya. A split-plot layout study was conducted at two sites differing in altitude and climatic conditions in Kenya: Kangaita $\left(0^{\circ} 30^{\prime} \mathrm{S}, 37^{\circ} 16^{\prime} \mathrm{E}, 2100\right.$ m.a.s.l. $)$ and Kipkebe $\left(0^{\circ} 17^{\prime} \mathrm{S}, 35^{\circ} 3^{\prime} \mathrm{E}, 1740\right.$ m.a.s.l.). Timbilil $\left(0^{\circ} 22^{\prime} \mathrm{S}, 35^{\circ} 21^{\prime} \mathrm{E}, 2200\right.$ m.a.s.l. $)$ was used as a reference site. Four tea clones of commercial and scientific interest in Kenya (AHP SC 31/37, EPK TN14-3, TRFK 301/5 and TRFK 31/8) were studied. Low radiation intensities at Timbilil in 2007 corresponded with low made tea yields at Kangaita $\left(2.1 \mathrm{tha}^{-1} \mathrm{y}^{-1}\right)$ and Kipkebe $\left(2.6 \mathrm{tha}^{-1} \mathrm{y}^{-1}\right)$ compared to $2008\left(4.4 \mathrm{tha}^{-1} \mathrm{y}^{-1}\right.$ and $\left.3.2 \mathrm{tha}^{-1} \mathrm{y}^{-1}\right)$ and $2009\left(3.1 \mathrm{tha}^{-1} \mathrm{y}^{-1}\right.$ and $\left.3.0 \mathrm{t} \mathrm{ha}^{-1} \mathrm{y}^{-1}\right)$ respectively when higher total radiation intensities were recorded. Statistical analysis done using two-way ANOVA $(\mathrm{P}=0.05)$ for split plot design showed a strong positive correlation $(\mathrm{r}=0.53)$ between total solar radiation, rainfall and mean made tea yield. Higher radiation and rainfall intensities yielded higher tea outputs.
\end{abstract}

Keywords: rainfall, split plot design, tea (Camellia sinensis), total solar radiation, yields

\section{Introduction}

Tea (Camellia sinensis [L.] O. Kuntze) is a rural-based agricultural enterprise and is the leading cash crop in Kenya, making significant contribution to the economy. Where it is grown, it employs $75 \%$ of rural population (Kiprono, Sudoi, M'ribu Kaburu, \& Mwaura, 2011). It is currently the single largest export commodity, accounting for about $26 \%$ of the country's total annual export earnings (Kilel, Wanyoko, Faraj, \& Wachira, 2013). Over $60 \%$ of the Kenyan tea is grown by smallholders. In 2017 , tea earned the country US $\$ 1.23$ billion (equivalent to Kenya shillings 129 billion) in foreign exchange earnings from 439 million $\mathrm{kg}$ of made tea exported (Kenya Agricultural and Livestock Research Organization-Tea Research Institute, 2018) and contributed about 4\% of Gross Domestic Product (GDP) (Kilel et al., 2013; Onduru, De Jager, Hiller, \& Van den Bosch, 2012). As a labour intensive industry, tea sector supports livelihoods of more than four million Kenyans (about $10 \%$ of total population) living in the rural areas directly and indirectly all-year round (Tea Board of Kenya, 2012; Onduru et al., 2012; Kenya Agricultural and Livestock Research Organization-Tea Research Institute, 2018).

Solar radiation is the primary driver of plant photosynthesis (White, Howden, \& Mark, 2009). Solar irradiance, $R_{s i}$, includes both direct beam and diffuse shortwave radiation reaching the earth's surface; and is defined as the radiant energy reaching a horizontal plane at the earth's surface (Evett, Matthias, \& Warrick, 1994). Photosynthetically active radiation (PAR-visible light spectrum) is of paramount importance in plant growth in that PAR light is responsible for driving photosynthesis (Tsubo \& Walker, 2005). PAR is defined as the waveband of blue and red region between $400 \mathrm{~nm}$ and $700 \mathrm{~nm}$ (Jones, 1992), and may be expressed on the basis of energy $\left(\mathrm{Wm}^{-2}\right)$ or as a stream of particles called quanta or photons $\left(\mathrm{mol} \mathrm{m}^{-2} \mathrm{~s}^{-1}\right)(\mathrm{McCree}, 1981)$. Tea production is affected by changes in weather. It requires at least 5 sunshine hours per day. Tea yields drops drastically under cloudy conditions and with heavy and continuous rainfall, just like it does when weather is hot, dry and sunny. For solar radiations above 350 $\mathrm{Wm}^{-1}$, Squire (1977) observed that single top leaves are photosynthetically light saturated while whole canopies 
require $700-800 \mathrm{Wm}^{-1}$, a value equivalent to full sunlight in the cooler seasons of many high altitude tea areas, and account for $75 \%$ of full sunlight in the warmer rainy seasons. The factors that have been documented to limit yield include: removal of young shoots (Tanton, 1979), air temperature (Ng'etich, Stephens, \& Othieno, 2001); Tanton, 1982a; Carr \& Stephens, 1992), soil temperature confounded with dry air (Tanton, 1982a; Othieno, Stephens, \& Carr, 1992; Odhiambo, Nyabundi, \& Chweya, 1993; Chen \& Fong, 1994; Nixon, Burgess, Sanga, \& Carr, 2001), hail (Ng'etich et al., 2001; Othieno et al., 1992), day-length (Tanton, 1982b), soil temperature (Ng'etich et al., 2001) and solar radiation (Squire, 1977). Falling temperatures and soil physical and chemical conditions greatly limits tea yield (Ng'etich et al., 2001). Radiation use efficiency $(e, \mathrm{~g} / \mathrm{MJ})$ describes the transformation efficiency from energy into dry matter of crop canopy (Carr \& Stephens, 1992).

The main climatic variables influencing yield of tea are temperature, the saturation deficit of the air and, through influence on plant and soil water deficits, rainfall and evapotranspiration (Stephens, Othieno, \& Carr, 1992). Saturation deficits (SD) above $2.3 \mathrm{kPa}$ in Malawi (Tanton, 1982b) and soil water deficits exceeding $40 \mathrm{~mm}$ in Tanzania (Stephens \& Carr, 1993) have been reported to reduce yields. In Kenya, yield reductions of $200 \mathrm{~kg} \mathrm{ha}^{-1}$ annually have been observed in commercial fields for every $100 \mathrm{~m}$ rise in altitude, mainly due to associated temperature differences. Other climatic variables such as water stress and low soil temperatures have also been reported to reduce tea yields (Othieno et al., 1992).

Limited information is available on work done on genotypes at different sites as the majority of research reporting the effects of weather on tea yields in Kenya has been carried at single sites only (Ng'etich et al., 2001; Burgess, 1992; Carr \& Stephens, 1992). The few that were done at different sites by Ng'etich (1995), Cheruiyot (2008) and Bore (2008) may need further follow-up to beef up on the G×E studies. Furthermore, information on the impact the total radiation has on the yield of tea (Camellia sinensis) genotypes is scanty.Resulting from reported temperature changes which may impact negatively on performance of tea, these positive gains may be lost if studies reporting the effects of weather on tea yields in Kenya is not diversified. This experiment was, therefore, undertaken to investigate the contribution of total solar radiation and rainfall to tea (Camellia sinensis) yields at two sites in Kenya. It is on this basis and the significant role tea contributes to Kenya's economy that the $\mathrm{G} \times \mathrm{E}$ evaluation of tea clones of the same age but planted at different agro-ecological sites was undertaken.

\section{Materials and Methods}

\subsection{Location and Treatments}

The study was conducted in three sites: Kipkebe $\left(0^{\circ} 17^{\prime} \mathrm{S}, 35^{\circ} 3^{\prime} \mathrm{E}\right.$ and 1740 masl. $)$ and Kangaita $\left(0^{\circ} 30^{\prime} \mathrm{S}, 37^{\circ} 16^{\prime} \mathrm{E}\right.$ and 2100 masl.). The third site, Tea Research Foundation of Kenya (TRFK)-Timbilil $\left(0^{\circ} 22^{\prime} \mathrm{S}, 35^{\circ} 21^{\prime} \mathrm{E}, 2200\right.$ masl.) acted as a reference site. A split-plot arrangement for sites was set out in an existing experiment that was established in 1998. It investigated the impact the total/incident solar radiation (ISR) and rainfall had on the yield of four tea genotypes of scientific and commercial importance to the country. This experiment had two factors: sites (environment, i.e. radiation and rainfall) (whole or main-plot factor) and genotypes (G i.e. yield) (split-plot factor). The treatments were 4 tea genotypes: EPK TN 14-3, TRFK 301/5, AHP SC 31/37 and TRFK 31/8. Clone TRFK $31 / 8$ was used as a standard (control) owing to its stability and wide distribution among the smallholder farmers in the region. Radiation, rainfall and yield measurements were carried out between 2007 and 2013.

\subsection{The Timbilil Total Solar Radiation Measurements}

PAR and total radiation measurements were taken thrice daily, i.e. 1000 hours, 1200 hours and 1400 hours, by use of ceptometer (PAR) and tube solarimeter (total radiation). Readings were taken on these two radiation measurement apparatus concurrently on top and beneath the canopy to obtain ceptometer versus tube solarimeter ratios, hence determine PAR $\left(\mathrm{mol} / \mathrm{m}^{2} / \mathrm{sec}\right)$. The KIPP and Zonensolarimeters were used to calibrate tube solarimeter where a conversion factor $(c f)$ of 0.706 was obtained. Direct solar irradiation, denoted $E_{d i r}\left(\mathrm{Wm}^{-2}\right)$, was then determined using Equation (1):

$$
E_{d i r}=\frac{(r \times c f) m V \times 1000}{11.7 \mathrm{mV}} \mathrm{Wm}^{-2}
$$

Where,

$r=$ Broadband direct radiation measurement (solarimeter); $c f=$ Conversion factor (Kangaita $=1.0$; Kipkebe $=$ 0.706; Timbilil $=0.986) ; 1000=$ To convert $\mathrm{Kwm}^{-2}$ energy units to $\mathrm{Wm}^{-2} ; 11.7=\mathrm{KIPP}$ calibration factor; $m V=$ millivolts.

\subsection{Intercepted Solar Radiation}

The fraction of solar energy intercepted by the canopy ( $\mathrm{Si}$ ), direct and PAR, is given by Equation (2): 
Where,

$$
S i=\frac{T i-B i}{T i}
$$

$T i\left(\mathrm{Wm}^{-2}\right)$ is irradiance captured on top of canopy while $B i\left(\mathrm{Wm}^{-2}\right)$ is that energy reaching beneath the tea bush (maintenance layer). Food reserves are stored in the maintenance layer of the canopy and used are used to maintain growth and development of the crop.

Gonzalez and Calbo (2002) defines photosynthetic photon flux density (PPFD) or $Q_{p}$, as a measure of PAR that can be related to solar broadband irradiance $R_{s}$ using Equation (3):

$$
Q_{p}=\varepsilon R_{s}
$$

Which can be applied either to global, direct or diffuse radiation. The ratio ' $\varepsilon$ ' (epsilon) can be considered as a product of two ratios: (i) the fraction of the broadband energy that lies in the PAR wave-band (400-700 nm), whose published values global irradiance are around 0.45 , and (ii) the photon or quantum efficiency of this band (Gonzalez \& Calbo, 2002). McCree (1972) gave the the value of $4.57 \mathrm{iE} / \mathrm{J}$ when both direct and diffuse radiation are present, and $4.24 \mathrm{iE} / \mathrm{J}$ when the radiation is purely diffused. Gonzalez and Calbo (2002), therefore, estimated values for $\varepsilon$ to be near $2 \mathrm{iE} / \mathrm{J}$. These figures are arrived at by use of measured light energy units, usually in millivolts or $\mathrm{Wm}^{-2}$.

$E_{d i r}$ can be converted from $\mathrm{Wm}^{-2}$ units to PAR $\left(\mathrm{mol} / \mathrm{m}^{2} / \mathrm{sec}\right)$. For an appropriate value over the waveband 400-700 nm (PAR), Skye Instruments Ltd. (2002) published that $\mathrm{Wm}^{-2}$ can be converted to $\mathrm{mol} / \mathrm{m}^{2} / \mathrm{sec}$ by multiplying by 4.6 (Equation 4 ):

\subsection{Rainfall Measurements}

$$
\frac{(119.708)}{\text { Wavelength }}=\frac{(1)}{4.6}
$$

Rain gauge recommended by Kenya Meteorology Department was used to measure the amount of rainfall at 0900 hours daily (Mwebesa, 1970). Water that collected in the glass bottle graduated in millimeters was poured into a measuring cylinder. When $0.05 \mathrm{~mm}$ or less was measured, the rainfall was recorded as trace. While taking readings, the measuring cylinder was held horizontal to the eye level to guard against parallax error.

\subsection{Yield Measurements}

Harvesting was done by selecting tender apical shoots growing above the pre-determined plucking table, notably two leaves and a bud at the top of tea canopy. The harvest of green leaf was based 14-day interval (twice a month) in the two trial sites. The Tea Research Foundation of Kenya (TRFK) has traditionally used a constant factor of 0.225 to convert green leaf mass to made tea $(\mathrm{mt})$ normally considered to have minimum moisture content of $3 \%$ (Anonymous, 1998, Ng'etich et al., 2001; Tea Board of Kenya, 2002). This TRFK published ratio was adopted for use in this study.

\subsection{Statistical Model and Analysis}

The statistical analysis was done using the split plot arrangement following the model:

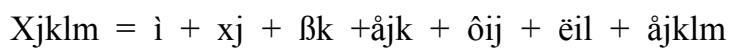

Where,

Xjklm = Plot observation; ì = Mean of observation; $\mathrm{xj}=$ Main treatment effect (Genotypes); $\mathrm{Bk}=$ Block/replication effect (A, B, C); åjk = Error (1); ôij = Sub-treatment effect (Environmental factors-E, i.e. direct radiation, PAR, rainfall, air temperature, yield); ëil = Interaction main treatment $(\mathrm{G})$ and the sub-treatment $(\mathrm{E})$; åjklm $=$ Error (2).

Two-way ANOVA ( $\mathrm{p}=0.05)$ for split plot design (GenStat, 2012; Stern, Arnold, Coe, \& Buysse, 2001) was used to determine significance of direct radiation (hence PAR) of genotypes and yield across locations and years. Correlation ANOVA (Pearson) was used to compare the relative strength of parameters and determine significance (interrelationships) between solar radiation, yield, temperature and rainfall (SPSS, 2011; Pallant, 2011).

\section{Results and Discussion}

\subsection{Kangaita and Kipkebe Intercepted Solar Radiation Ratio ( $\left.\sum R S i\right)$}

Equation (2) was used to compute fraction of intercepted $E_{d i r}\left(\mathrm{Wm}^{-2}\right)$ by the canopy of the clones $\left(\sum R S i\right)$ between 2007 and 2009. 
Table 1. Fraction of $E_{d i r}\left(\mathrm{Wm}^{-2}\right)$ intercepted by tea canopy of the clones cummulatively $\left(\sum R S i\right)$ at Kangaita, 2007-2009

\begin{tabular}{lllllll}
\hline \multirow{2}{*}{ Year } & \multicolumn{5}{c}{$\sum R S i$ (unitless) on the tea clones } & \multirow{2}{*}{ No. of rain days } \\
\cline { 2 - 6 } & $301 / 5$ & $31 / 37$ & $31 / 8$ & TN 14-3 & Annual mean & \\
\hline 2007 & 0.83 & 0.82 & 0.81 & 0.82 & 0.82 & 163 \\
2008 & 0.83 & 0.82 & 0.83 & 0.82 & $0.82 \leftrightarrow$ & $152 \downarrow$ \\
2009 & $0.79^{*}$ & $0.79^{*}$ & $0.78^{*}$ & $0.79^{*}$ & $0.79^{*} \downarrow$ & $134 \downarrow$ \\
Mean & 0.82 & 0.81 & 0.81 & 0.81 & 0.81 & \\
SED & \pm 0.023 & \pm 0.017 & \pm 0.025 & \pm 0.017 & & \\
\hline
\end{tabular}

Note. * Less radiation intercepted by tea clones at Kangaita in 2009 due to leaf fall occasioned by drought; $\leftrightarrow=$ Figure remained constant (unchanged); $\downarrow=$ Figure decreased.

\subsubsection{Kangaita}

It was expected that progressive canopy formation should have hindered more light penetration to maintenance layer in 2009, raising the $\sum R S i$ ratio (Table 1 ). The canopy allowed the highest intensity of ISR (21\%) to penetrate into the lower layers of the leaves compared to the first 2 years (2007 and 2008) of the trial. This could have been due to reduced interception of light caused by water stress, which was occasioned by reduced number of rain days from 152 (2008) to 134 (2009). Rainfall facilitates tea canopy establishment, contributing to maximum ISR interception. Low mean monthly rainfall at Kangaita in 2009 (134 mm) compared to the first 2 years (183 $\mathrm{mm}$ in 2007 and $147 \mathrm{~mm}$ in 2008, Table 4) of this trial, coupled with fewer number of rainy days recorded the same year (134 days) compared to the preceding 2 years led to moisture content deficit in the soil, causing senescent leaves to fall off. Limited number of young leaves was, therefore, unable to shield the lower layers and allowed more light to penetrate to the maintenance layer, resulting in reduced harvestable leaves, hence lower yield.

\subsubsection{Kipkebe}

Irradiance penetration to the maintenance layer was more pronounced in 2007 (60\% on average across the treatments) compared to the subsequent years (78\% in 2008 and $83 \%$ in 2009) (Table 2). Two reasons may have led to less radiation interception in 2007, hence less dense canopy: (i) Insufficient rainfall in 2007 (mean monthly of $112 \mathrm{~mm}$ ) compared to Kangaita $(183 \mathrm{~mm}$, Table 4) may have resulted in slow growth of the vegetative parts of the plants leading to reduced canopy density, poor ground cover formation as was the case with Kangaita; (ii) Slow recovery of the clones following pruning carried out in February 2007. Unlike the Kangaita trial where more light energy penetrated into the maintenance layer (reduced light interception) in the third year (2009) of trial due to leaf fall, the Kipkebe experiment followed the expected solar interception cycle. Light interception indicated a progressive canopy development such that by 2009, a more dense canopy had been formed, resulting in more interception of light than in the 2 preceding years (Table 2), in which more light was intercepted with time as a result of build-up of denser canopy. Low direct radiation in 2007 resulted in low yields (2.6 $\mathrm{t} \mathrm{ha}^{-1} \mathrm{y}^{-1}$ ) compared to 2008 and 2009 (3.2 $\mathrm{t} \mathrm{ha}^{-1} \mathrm{y}^{-1}$ and $3.0 \mathrm{t} \mathrm{ha}^{-1} \mathrm{y}^{-1}$ respectively) (Table 4). TN 14-3 was the most effective in irradiation interception (77\%, SED \pm 0.117$)$, while clone 301/5 allowed most of direct irradiance to the maintenance layer $(73 \%, \mathrm{SED} \pm 0.101)$.

Table 2. Fraction of Direct Radiation $\left(\mathrm{Wm}^{-2}\right)$ CummulativelyIntercepted by Tea Canopy of the Clones $\left(\sum R S i\right)$ at Kipkebe, 2007-2009

\begin{tabular}{llllll}
\hline \multirow{2}{*}{ Year } & \multicolumn{5}{c}{$\sum R$ Sion the tea clones } \\
\cline { 2 - 5 } & $301 / 5$ & $31 / 37$ & $31 / 8$ & TN 14-3 & Annual mean \\
\hline 2007 & 0.61 & 0.58 & 0.57 & 0.64 & 0.60 \\
2008 & 0.78 & 0.78 & 0.78 & 0.79 & $0.78 \uparrow$ \\
2009 & 0.79 & 0.82 & 0.83 & 0.87 & $0.83 \uparrow$ \\
Mean & 0.73 & 0.73 & 0.73 & 0.77 & 0.74 \\
SED & \pm 0.101 & \pm 0.129 & \pm 0.138 & \pm 0.117 & \\
\hline
\end{tabular}

Note. $\uparrow=$ Interception increased. 
With $E_{\text {dir }}$ standard deviation of 150.8 for Kangaita and 97.4 for Kipkebe for the 3 year period, the graph shown as Figure 1 was generated with standard error bars.

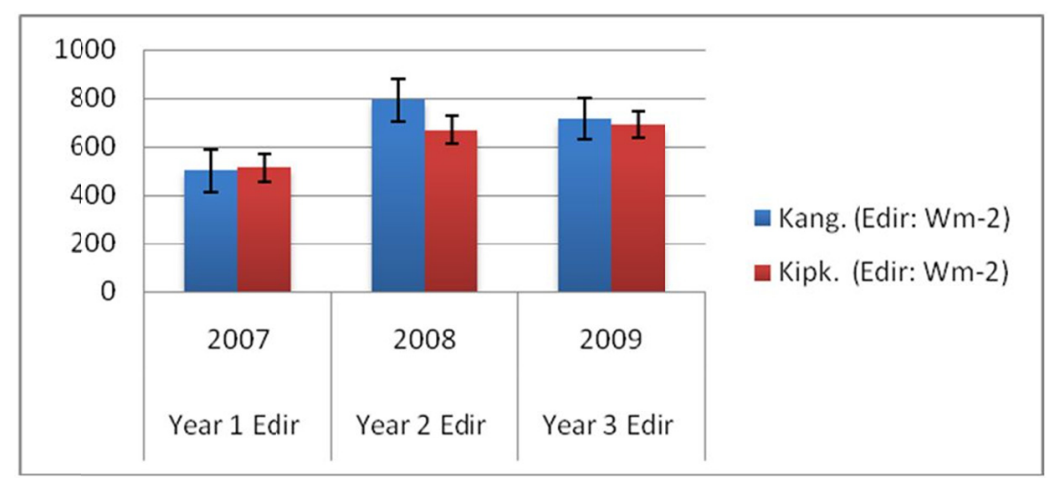

Figure 1. Comparison of $E_{d i r}\left(\mathrm{Wm}^{-2}\right)$ at Kangaita and Kipkebe in 3 Years of Study by Columns with Standard Error Bars

\subsection{3 $E_{\text {dir }}\left(\mathrm{Wm}^{-2}\right)$ Across Locations}

Direct radiation $\left(E_{d i r}\right)\left(\mathrm{Wm}^{-2}\right)$ measurements at the top and base of tea canopy is shown in Table 3.

Table 3. Summary of Kangaita and Kipkebe daily mean $E_{\text {dir }}\left(\mathrm{Wm}^{-2}\right)$ measurements, 2007-2009

\begin{tabular}{lllllll}
\hline \multirow{2}{*}{ Site } & \multirow{2}{*}{ Position } & \multicolumn{5}{c}{ Treatment (tea clones) } \\
\cline { 3 - 6 } & & $301 / 5$ & $31 / 37$ & $31 / 8$ & TN 14-3 & Annual Mean \\
\hline Kipkebe & Mean for Top & 623 & 624 & 625 & 627 & 625 \\
\hdashline Kangaita & Mean for Base & 168 & 160 & 161 & 138 & 157 \\
& Mean for Top & 677 & 656 & 692 & 656 & 670 \\
\hline
\end{tabular}

\subsubsection{Clonal (G) Statistical Analysis (Univariate ANOVA)}

The three-year clonal marginal means of radiation on top of canopy were subjected to univariate ANOVA. A positive correlation between clones existed in the estimated marginal means measured between 2007 and 2009 (Figure 2). The top canopy of clone 301/5 at Kangaita harvested the highest quantities of irradiance in 2007, while clone $31 / 8$ recorded the highest in both 2008 and 2009. The outcome depicts clone $31 / 8$ as a widely adapted variety.
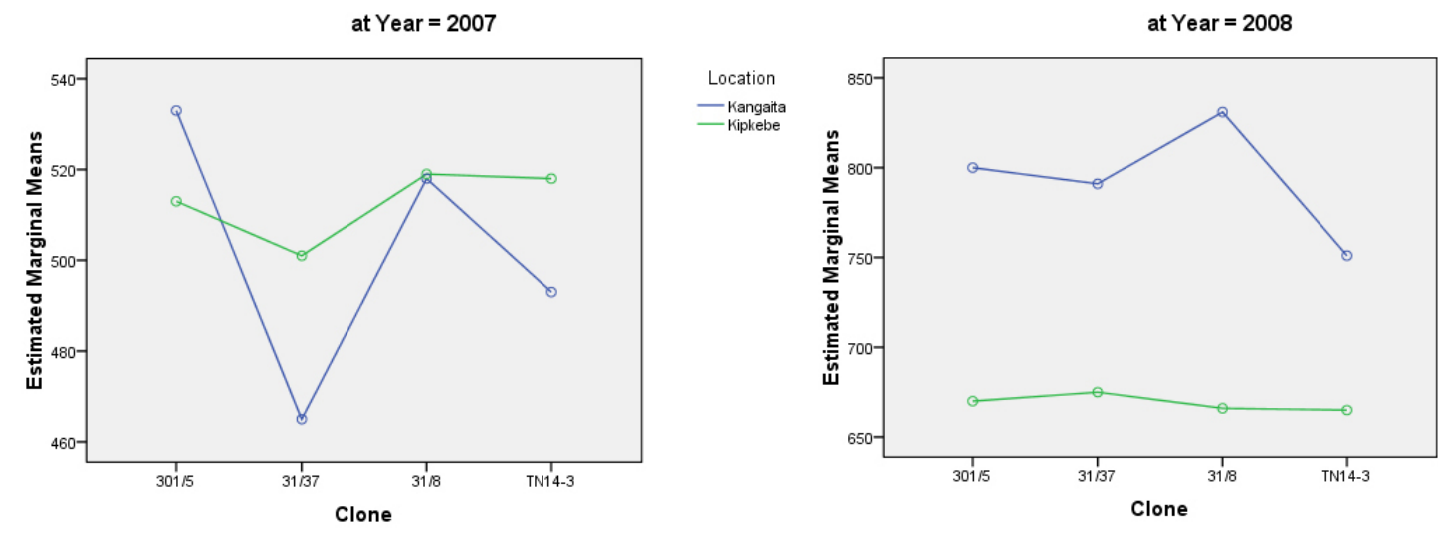


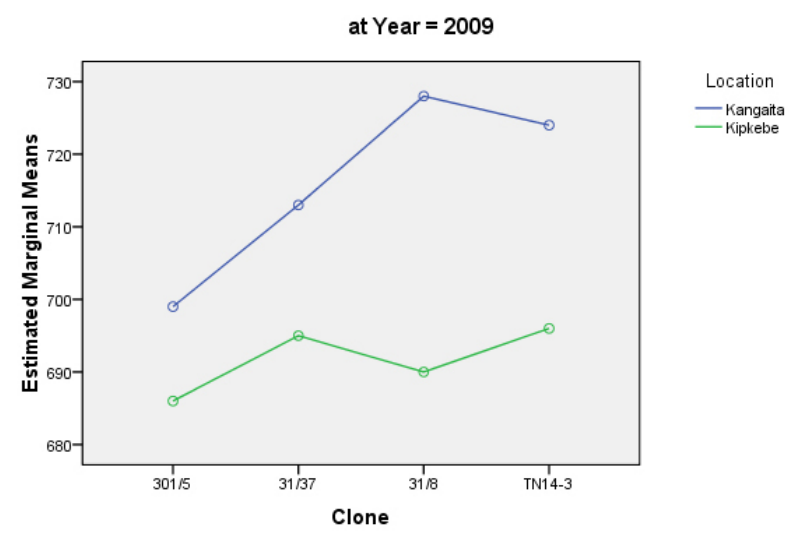

Figure 2. Clonal Univariate ANOVA to Estimate Radiation Marginal Means AcrossKangaita and Kipkebe in the 3-year Period

\subsection{Relationship Between Rainfall and Yield in Tea}

\subsubsection{Kangaita}

Precipitation amount is a critical factor that influence crop yield (Stephens et al., 1992). In the Kangaita trial however, the experiment produced the following results: in 2007, a total of $2197 \mathrm{~mm}$ was received, while the average clonal yield comprised $2.1 \mathrm{tha}^{-1} \mathrm{y}^{-1}, 1765 \mathrm{~mm}$ in $2008\left(4.4 \mathrm{tha}^{-1} \mathrm{y}^{-1}\right)$ and $1613 \mathrm{~mm}$ in $2009\left(3.1 \mathrm{tha}^{-1} \mathrm{y}^{-1}\right)$ (Table 4). From these findings, periods having lower rainfall amounts gave higher yields. Higher rainfall amounts did not translate to higher yields compared to the impact the $E_{\text {dir }}$ had on the tea crop yield. Interception directly impacted on tea crop yield.

\subsubsection{Kipkebe}

The 2007 monthly precipitation of $112 \mathrm{~mm}$ realized a clonal average yield of $2.6 \mathrm{tha}^{-1} \mathrm{y}^{-1}$, while the $2008(129 \mathrm{~mm})$ and $2009\left(128 \mathrm{~mm}\right.$ ) gave bigger yields of $3.2 \mathrm{ha}^{-1} \mathrm{y}^{-1}$, and $3.0 \mathrm{ha}^{-1} \mathrm{y}^{-1}$, respectively (Table 4). While rainfall amounts at Kangaita did not seem to have significantly influenced yield, rainfall was a significant factor at Kipkebe in that it contributed towards determination of yield volume as suggested by Stephens et al. (1992).

\subsection{Total Radiation and Yield Relations}

Yield data (Table 4) showed that 2007 produced least mean clonal outputs for both Kangaita $\left(2.1 \mathrm{tha}^{-1} \mathrm{y}^{-1}\right)$ and Kipkebe $\left(2.6 \mathrm{t} \mathrm{ha}^{-1} \mathrm{y}^{-1}\right)$, compared to the subsequent years. In 2008 and 2009, the number of sunshine hours went up by a digit (7.0 hours; $20.3 \mathrm{MJ} \mathrm{m}^{-2}$ and 7.1 hours; $21.7 \mathrm{MJ} \mathrm{m}^{-2}$ respectively, Table 5) with standard error of deviation (SED) of \pm 0.493 , evidently raising yields, i.e. $4.4 \mathrm{t} \mathrm{ha}^{-1} \mathrm{y}^{-1}$ for Kangaita and $3.2 \mathrm{t} \mathrm{ha}^{-1} \mathrm{y}^{-1}$ for Kipkebe in 2008 (Table 4). Monthly direct solar radiation measurements for 3 years (2007-2009) showed no significant difference, with radiation mean monthly output of $21.2 \mathrm{MJ} \mathrm{m}^{-2}$ and SED $= \pm 0.757$. The low total radiation in 2007 is attributed to higher cloud cover experienced in 2007 compared to 2008 and 2009, resulting in reduced yield. The outcome therefore, depicts close relationship between total radiation and yield.

Table 4. The 2007-09 yield, temperature and rainfall at Kangaita and Kipkebe

\begin{tabular}{llllllll}
\hline \multirow{2}{*}{ Year } & \multicolumn{3}{c}{ Kangaita } & & \multicolumn{3}{c}{ Kipkebe } \\
\cline { 2 - 3 } & Yield $\left(\right.$ tons ha $\left.{ }^{-1} \mathrm{y}^{-1}\right)$ & Temp. $\left({ }^{\circ} \mathrm{C}\right)$ & Rainfall $(\mathrm{mm})$ & & Yield (tons ha $\left.{ }^{-1} \mathrm{y}^{-1}\right)$ & Temp. $\left({ }^{\circ} \mathrm{C}\right)$ & Rainfall $(\mathrm{mm})$ \\
\hline 2007 & 2.080 & 15.5 & $183.0(2197)$ & & 2.586 & 20.0 & $111.6(1339)$ \\
2008 & 4.425 & 15.2 & $147.1(1765)$ & & 3.176 & 20.0 & $128.6(1544)$ \\
2009 & 3.086 & 15.6 & $134.4(1613)$ & & 2.962 & 20.0 & $134.0(1607)$ \\
\hline
\end{tabular}


Table 5. Mean monthly radiation ( $\mathrm{MJ} \mathrm{m}^{-2}$ ) and daily sunshine hours, 2007-2009 at Timbilil

\begin{tabular}{llllll}
\hline Year & 2007 & 2008 & 2009 & Mean & SED \\
\hline Mean daily sunshine hours (No.) & 6.2 & 7.0 & 7.1 & 6.8 & \pm 0.493 \\
Monthly radiation means (MJ m ${ }^{-2}$ ) & 20.3 & 21.5 & 21.7 & 21.2 & \pm 0.757 \\
\hline
\end{tabular}

\subsubsection{Correlation Coefficient (r) Analysis: Total Solar Radiation Versus Yield}

Correlation coefficient (r) analysis between clonal yield (Table 4) measured from 2007 to 2009 in relation to Timbilil total radiation (Table 5) returned $\mathrm{r}=0.53$, depicting a strong positive correlation between the two variables (yield and solar radiation).

\subsubsection{Statistical Analysis}

ANOVA (GenStat, 2012) was carried out to determine significance of yield between clones (as blocks). Treatments were the 2 sites and 3 years, while yield (tons $\mathrm{ha}^{-1} \mathrm{yr}^{-1}$ ) was the only variate (Table 6).

Table 6. ANOVA of clonal yield within and across sites (Variate: Yield)

\begin{tabular}{llllll}
\hline Source of variation & d.f. & s.s. & m.s. & v.r. & F pr. \\
\hline Clone stratum & 3 & 0.7110 & 0.2370 & 0.68 & \\
Site & 1 & 0.5011 & 0.5011 & 1.45 & 0.248 \\
Year & 2 & & & & $<0.01 * *$ \\
Site.Year & 4 & 11.7848 & 2.9462 & 8.50 & \\
Residual & 15 & 5.1995 & 0.3466 & & \\
Total & 23 & 18.1965 & & & \\
\hline
\end{tabular}

Note. ${ }^{* *}$ : Statistical significant difference exists at $\leq 0.01$.

Yields across sites within the year were not different statistically, but highly significant (F ratio $\leq 0.01$ ) across the 2 sites during the 3-year measurement.

Correlations between variables: bivariate 2-tailed correlation (Pearson) method was used to determine interaction correlations between variables (Table 7). Equation (3) was used to convert $R s\left(\mathrm{Wm}^{-2}\right)$ to PAR.

Table 7. Bivariate 2-tailed pearson correlation method to determine interaction correlations between variables

\begin{tabular}{lllllll}
\hline Parameter interactions & Yield & Location/Site & Genotype PAR & Year & Temperature & Rainfall \\
\hline Yield & 1 & -0.166 & -0.078 & 0.324 & -0.197 & -0.173 \\
Location/Site & -0.166 & 1 & 0.000 & 0.000 & $0.999^{* *}$ & $-0.684^{* *}$ \\
Genotype PAR & -0.078 & 0.000 & 1 & 0.000 & 0.000 & 0.000 \\
Year & 0.324 & 0.000 & 0.000 & 1 & 0.009 & -0.244 \\
Temperature & -0.197 & $0.999^{* *}$ & 0.009 & 0.009 & 1 & $-0.682^{* *}$ \\
Rainfall & -0.173 & $-0.684^{* *}$ & -0.244 & -0.244 & $-0.682^{* *}$ & 1 \\
\hline
\end{tabular}

Note. **: Correlation is significant at the 0.01 level (2-tailed).

Correlation coefficient of rainfall across the 3 locations (Table 7) was also found to be (highly) statistically different from zero $(\mathrm{P} \leq 0.01)$.

\section{Conclusions}

There was a steady rise in total radiation per annum at Timbilil between 2007 and 2009, suggesting signs of changing weather patterns. A strong positive relationship exists between total solar radiation and yield. Rainfall was a significant factor in determining yield volumes at both Kipkebe and Kangaita. Temperature influenced yield as higher temperature resulted in more yield on average in the three-year period. Statistical analysis revealed a strong positive correlation $(r=0.53)$ between total solar radiation, rainfall and mean made tea yield as higher radiation and rainfall intensities resulted in higher tea outputs. 


\section{References}

Anonymous. (1998). Human nutrition in Tropical Africa (pp. 229-230).

Bore, J. K. (2008). Physiological responses of grafted tea (Camellia sinensis) to water stress (PhD. Thesis, Egerton University, Njoro, Kenya).

Burgess, P. J. (1992). Response of tea clones to drought in Southern Tanzania (PhD thesis, Granfield Institute of Technology, Silsoe College, UK).

Carr, M. K. V., \& Stephens, W. (1992). Climate, weather and yield of tea. In K. C. Willson \& M. N. Clifford (Eds.), Tea: Cultivation to consumption. London: Chapman and Hall. https://doi.org/10.1007/978-94-011-2326-6_4

Chen, H., \& Fong, C. H. (1994). Drought damages and related factors in tea (Camellia sinensis) in Taiwan.Chinese Journal of Agrometeorology, 1, 133-141.

Cheruiyot, E. K. (2008). The influence of soil water content and nitrogen supply on growth, yield and polyphenol content of selected tea (Camellia sinensis [L.] O. Kuntze) clones in Kenya ( $\mathrm{PhD}$ thesis, Egerton University, Kenya).

Evett, S. R., Matthias, A. D., \& Warrick, A. W. (1994). Energy balance model of spatially variable evaporation from bare soil. Soil Sci. Soc. Amer. J., 58, 1604-1611. https://doi.org/10.2136/sssaj1994.03615995005800 $060003 \mathrm{x}$

GenStat. (2012). GenStat for Windows (10th ed.). VSN International, Hertfordshire, UK.

Gonzalez, J. A., \& Calbo, J. (2002). Modelled and measured ratio of PAR to global radiation under cloudless skies. Agricultural and Forest Meteorology, 110, 319-325. https://doi.org/10.1016/S0168-1923(01)00291-X

Jones, H. G. (1992). Plants and microclimate-A quantitative approach to environmental plant physiology (2nd ed., pp. 9-45). Cambridge University Press, Cambridge CB2 IRP.

Kenya Agricultural and Livestock Research Organization-Tea Research Institute. (2018). Field Services Co-ordinators, Kenya Tea Development Authority (KTDA) Conference. Sunshine Upper Hill Hotel, Kericho, Kenya.

Kilel, E. C., Wanyoko, J. K., Faraj, A. K., \&Wachira, F. N. (2013). Plain black tea quality parameters of purple leaf coloured tea clones in Kenya. International Journal of Research in Chemistry and Environment, 3(3), 81-88.

Kiprono, P. K., Sudoi, V. K., M'ribu Kaburu, \& Mwaura, F. K. (2011). The socio-economic factors influencing productivity of the smallholder subsector of the Kenyan tea industry: A survey of Nandi District. International Journal of Current Research, 3(10), 031-034.

McCree, K. J. (1972). Test of current definitions of photosythetically active radiation against leaf photosynthesis data. Agricultural and Forest Meteorology, 10, 443-453. https://doi.org/10.1016/0002-1571(72)90045-3

McCree, K. J. (1981). Photosynthetically active radiation. In O. L. Lange, P. S. Nobel, C. B. Osmond, \& H. Zeigler (Eds.), Encyclopedia of Plant Physiology (New Series, Vol. 12A, pp. 41-55). Springer, Berlin. https://doi.org/10.1007/978-3-642-68090-8_3

Mwebesa, M. M. N. (1970). East African Observer's Handbook (1st ed., pp. 110-133). A handbook of standard procedures for surface weather observing and recording of climatological data. East African Meteorological Department.

Ng'etich, W. K. (1995). An evaluation of the responses of some Kenyan tea clones to environment in Kenya (Ph.D. thesis, Cranfield University, Silsoe Campus, Institute of Water and Environment, UK).

Ng'etich, W. K. (1997). Response of tea to environment. Tea, 18(2), 149-155.

Ng'etich, W. K., Stephens, W., \& Othieno, C. O. (2001). Response of tea to environment in Kenya. 3. Yield and yield distribution. Expl. Agric., 37, 361-372. https://doi.org/10.1017/S0014479701003076

Nixon, D. J., Burgess, P. J., Sanga, B. N. K., \& Carr, M. K. V. (2001). A comparison of the responses of mature and young clonal tea to drought. Experimental Agriculture, 37, 391-402. https://doi.org/10.1017/ S001447970100309X

Odhiambo, H. O., Nyabundi, J. O., \& Chweya, J. (1993). Effects of soil moisture and vapour pressure deficits on shoot growth and yield of tea in the Kenyan highlands. Experimental Agriculture, 29, 341-350. https://doi.org/10.1017/S0014479700020901 
Onduru, D. D., De Jager, A., Hiller, S., \& Van den Bosch, R. (2012). Sustainability of smallholder tea production in developing countries: Learning experiences from farmer field schools in Kenya. International Journal of Development and Sustainability, 1(3).

Othieno, C. O., Stephens, W., \& Carr, M. K. V. (1992). Yield variability at the Tea Research Foundation of Kenya. Agricultural and Forest Meteorology, 61, 237-252. https://doi.org/10.1016/0168-1923(92)90052-6

Pallant, J. (2011). SPSS survival manual (4th ed.). A step by step guide to data analysis using the SPSS programme.

Skye Instruments Ltd. (2012). Appendix 3 on Conversion of measurements between mmol m $\mathrm{msec}^{-1}$ and $\mathrm{Wm}^{-2}$ (p. 12). Light Guidance Notes, SIL-UK.

SPSS Statistics 17.0. (2011). SPPS Incorporation. Retrieved from http://www.spss.com

Squire, G. R. (1977). Seasonal changes in photosynthesis of tea (Camellia sinensis). Journal of Applied Ecology, 14, 303-316. https://doi.org/10.2307/2401847

Stephens, W., \& Carr, M. K. V. (1993). Responses of tea (Camellia sinensis) to irrigation and fertilizer. III. Shoot extension and development. Experimental Agriculture, 29, 323-339. https://doi.org/10.1017/S00144797 00020895

Stephens, W., Othieno, C. O., \& Carr, M. K. V. (1992). Climate and weather variability at the Tea Research Foundation of Kenya. Agricultural and Forest Meteorology, 61, 219-235. https://doi.org/10.1016/ 0168-1923(92)90051-5

Stern, R., Arnold, G., Coe, R., \& Buysse, W. (2001). Using GenStat for Windows in Agriculture and Experimental Biology (5th ed., p. 204). ICRAF Nairobi, Kenya.

Tanton, T. W. (1979). Some factors limiting yield of tea (Camellia sinensis). Experimental Agriculture, 15, 187-191. https://doi.org/10.1017/S0014479700000594

Tanton, T. W. (1982a). Environmental factors affecting yield of tea (Camellia sinensis). I. Effects of air temperature. Experimental Agriculture, 18, 47-52. https://doi.org/10.1017/S0014479700013417

Tanton, T. W. (1982b). Environmental factors affecting yield of tea (Camellia sinensis). II. Effects of soil temperature, daylength and dry air. Experimental Agriculture, 18, 53-63. https://doi.org/10.1017/ S0014479700013429

Tea Board of Kenya. (2002). Tea Growers Handbook (5th ed.). A Publication of Tea Research Foundation of Kenya. Tea Board of Kenya, Nairobi, Kenya.

Tea Board of Kenya. (2012). Kenya tea industry performance report for 2011 and projections for 2012. A Publication by the Tea Board of Kenya, Naivasha Road, Nairobi, Kenya.

Tsubo, M., \& Walker, S. (2005). Relationships between photosynthetically active radiation and clearness index at Bloemfontein, South Africa. Theoretical and Applied Climatology, 80, 17-25. https://doi.org/10.1007/ s00704-004- 0080-5

White, D., Howden, H., \& Mark, S. (2009). Climate and its effects on crop productivity and management. In W. H. Verheye (Eds.), Crop and Soil Sciences. Encyclopedia of Life Support Systems (EOLSS), Developed under the Auspices of the UNESCO, EOLSS Publishers, Oxford, UK.

\section{Copyrights}

Copyright for this article is retained by the author(s), with first publication rights granted to the journal.

This is an open-access article distributed under the terms and conditions of the Creative Commons Attribution license (http://creativecommons.org/licenses/by/4.0/). 